\title{
Factors Associated with Work Safety of Domestic Helping Hands in Dhaka City, Bangladesh
}

\section{Rubaiul Murshed ${ }^{1 *}$, Rishad Choudhury Robin ${ }^{1}$, Mohammed Misbah Uddin $^{1}$ and Ahmed Mushtaque Raza Chowdhury ${ }^{2}$}

${ }^{1}$ Shomman Foundation, Dhaka, Bangladesh

${ }^{2}$ BRAC University, Dhaka, Bangladesh

*Corresponding Author: Rubaiul Murshed, Shomman Foundation, Dhaka, Bangladesh.

\author{
Received: August 23, 2021
}

Published: October 04, 2021

(C) All rights are reserved by Rubaiul

Murshed., et al.

\begin{abstract}
Domestic Helping Hands are one of the most vulnerable and exploited groups among informal workers in Bangladesh and the world. Considering their vulnerabilities, this cross-sectional study was carried out in Dhaka city to determine the factors associated with the working environment and safety of the Domestic Helping Hands. In this study, a total of 300 samples were interviewed faceto-face during 2017-2019 using a pre-coded structured survey questionnaire. The research found that $70.7 \%$ of respondents can not avail themselves any weekend and do not get any treatment if they become sick, 39.3\% are physically tortured, and $67.3 \%$ do not receive their wages in time. A total of $74 \%$ of respondents are confined under lock and key when all other household members go out. There is solid evidence of a violation of the existing laws, and the respondents do not get any written contract for the services. Therefore, the victims cannot take any legal measures for breach of the service rules and conditions. Establish a robust complaint response mechanism with a dedicated helpline number, insurance policy, Domestic Helping Hand trade union, and institutionalizing their services to shape them according to legal protection policies.
\end{abstract}

Keywords: Work Safety; Bangladesh; Domestic Helping Hand

\section{Introduction}

Bangladesh is a country with more than two million domestic helping hands (DHHs). This is one of the biggest informal sectors in the country. This work may comprise cleaning the house, cooking, washing and ironing clothes, taking care of children or elderly or sick family members, gardening, guarding the house, driving and even taking care of domestic pets. A DHH may work on a full-time or part-time basis; may be employed by a single household or by multiple employers; may be residing in the employer's household (live-in worker) or living in their residence (live-out). A domestic worker may be working in a country of which they are not a national [1]. In Bangladesh, many of them have migrated out of poverty from the rural to urban areas and adopted this profession as a livelihood strategy [2]. Even though a sizable number of men work in the sector (often as gardeners or drivers), it remains a highly feminized sector, with about $80 \%$ of all domestic workers being women. The International Labour Organization (ILO) says about one in twenty-five women workers worldwide are domestic workers [3]. It is estimated that there are currently about 67 million domestic workers worldwide, excluding children [4]. Surprisingly, most of the DHHs are vulnerable in their host households. DHH usually works until midnight and often conducts drudgery and challenging work in their host households for long hours without recognition. Their dignity, fundamental human rights, nutrition 
and wages are often compromised. As they have limited opportunities, their employers, who are often the middle- and upper-class in the society, capitalize on it. The employers do not recognize their rights to get minimum wages, allowances, fixed working hours, leave, bonuses, weekly holiday, maternity benefits etc. As a result, they do not get any leave during any festival period [1].

In Bangladesh, the phenomenon of child domestic workers is widespread. There are almost two million domestic workers, of which about a quarter are children. According to a Baseline survey, approximately 400,000 Child Domestic Workers aged 6-17 years in Bangladesh. This group of child workers is always cheap, invisible, and a high-risk group for abuse and exploitation. A problem for this informal sector is that it is always the adults who decide on the fate of child domestic workers, and when the children are in the employers' household, they live under the overall control of the employers. In these circumstances, the children have no opportunity to make their own choice or decision [5]. About one-third of domestic helpers who work in Dhaka are children, are driven by poverty and hunger as they have no one to look after them, the study said [6]. Typically, there are no specified hours or tasks allocated to child domestic workers. They do what their employer asks them to, at any time of day or night. Other essential issues children trapped in domestic child labor from a very young age are likely to have had no or insufficient access to education. At the same time, child domestic workers above the legal minimum age have a reduced chance of continuing with education [7]. Sometimes, to escape the persistent abuse and torture, many child domestic workers try to run their employers' household. But these desperate, instead of reaching their homes, children may haplessly die due to accidents or fall victims of traffickers or other criminal gangs who use them as their tools. Sometimes in the name of employing children, they are taken away from their homes in rural areas to cities and get trafficked or forced to engage in begging, prostitution or other immoral or illegal activities [8]. Here, child domestic workers are grossly exploited. They do not have ways to ventilate their grievances. They do not have any practical and effective legal process to enforce their rights or to ensure their benefits and privileges [9]. There is no monitoring system in the domestic worker protection system. Domestic workers have no scope for complaint [10].

On the other hand, Hundreds of Bangladeshi women working as domestic helpers in Saudi households have accused their employers of committing severe physical, mental and sexual abuses.
They face food and wage deprivation, physical torture and sexual exploitation, among other abuses. Many of them have no means of communication with outsiders as many of these girls and women are kept isolated from the outside world by their Saudi employers. Thousands of Bangladeshi female domestic workers have returned from Saudi Arabia. There are cases where these girls came back pregnant after suffering severe sexual abuse at the hands of their male employers. Others have faced brutal physical torture, including broken hands and other body parts [11].

The Government of Bangladesh had earlier promulgated an Ordinance for the registration of Domestic workers in some regions of Bangladesh. This Ordinance does not touch any regulatory aspect and does not confer any rights or remedies to the domestic workers [12].

On 21 December 2015, the Bangladesh government approved the Domestic Workers' Protection and Welfare Policy (DWPWP) 2015. The adoption of this policy is seen by many as a milestone in achieving legal recognition for those in domestic service. The DWPWP has sixteen provisions, with clearly specified responsibilities for the employers, the workers and the government [13]. Although the Bangladesh Government approved (DWPWP) 2015 with a key provision of registration and legal assistance for workers [14], its enforcement remains an open question.

As the DHHs are primarily invisible in intellectual or media discourse, their safety and well-being have largely been ignored. This research examines the factors associated with their work safety. We defined domestic help as those serving in sample households for at least six months on a full or part-time basis with verbal understanding in Dhaka city.

\section{Methodology}

A cross-sectional study design was followed in this research. The data was collected over an extended period of time spanning between October 2016 and September 2019. A multistage random sampling method was used. Firstly, one of the two municipal corporations under the City of Dhaka was randomly selected. Then ten wards were chosen randomly from the Corporation's 75 wards. Based on a guesstimate, there are about 1,100 DHHs in these ten words. Using Cochran's formula, a sample size of 312 was included for the study [15]. However, due to the decline of some respondents, we ended up with 300 interviews. The final samples were 
selected through a systematic procedure following the inclusion criteria. In households with more than one helping hand, one was selected at random.

Data were collected using a close-ended questionnaire consisting of four sections:

- Socio-demographics (gender, age, education, and marital status)

- Work status (working pattern, working time and job satisfaction)

- Health status (feeling of fatigue and receipt of treatment).

- Work Safety (use of proper utensils to carry hot water, buckets and availability of proper cleaning equipment while cleaning rooms, toilets, and stairs)

Although informed consent was obtained from all respondents before the interview, securing permission from their employers was one of the most challenging tasks during data collection. Six interviewers, three males and three females, carried out the data collection. The interviewers were trained on the questionnaire and the data collection process by the principal researcher (RM).

The content validity of the questionnaire was determined by item objective congruence (IOC). Three experts examined the questionnaire item-by-item. Only Items with IOC index of $>0.5$ were retained. A prior pilot survey conducted on 30 helping hands helped to modify the questionnaire.

The data were analyzed using SPSS version 20 for Windows. Descriptive statistics were generated to describe basic socio-demographic characteristics. Chi-square tests were used for the univariate analyses to determine the relationship between the study outcome and other demographic characteristics. Finally, a binary logistic regression was used for the multivariate analyses to investigate factors associated with the research outcome. The odds ratios (OR) with their corresponding confidence intervals (CIs) were presented for all variables. Unless otherwise stated, $\mathrm{p}$-values and CIs were set at $<0.05$ and $95 \%$, respectively.

\section{Results}

Table 1 shows the different socio-demographic characteristics of the helping hands. A vast majority of the respondents were fe- male (92\%). Thirty nine percent of them were aged 20 years or over, and $11 \%$ were children under 12 years of age. Sixty percent were unmarried and most (86\%) had completed primary schooling. Thirty-five percent earned an income of Tk 3000 or less per month, while a third reported a monthly payment of Tk 5000 or more. The table also presents the self-perceived feeling of 'safety' by the respondents in their respective places of work according to different characteristics. A large majority of the female helping hands felt unsafe (72.2\%). Safety decreased with decreasing age. Single respondents felt more unsafe than those married or widowed. Education did not appear to have any particular role in the safety situation as most respondents who read up to primary level felt that they were 'unsafe' and a vast majority of those who did not have any schooling felt 'safe'. Monthly income seemed to be a good predictor of work safety. Statistically, gender, marital status, education, and monthly income significantly affected work safety.

Table 2 gives further information on the sample helping hands. A majority of the helping hands were part-timers (65.6\%). Almost nobody was satisfied with their work. Two-thirds of them reported that they were not given their salary on time. More than a half of them worked for four to seven hours (as majorities were parttimers), while a fifth worked for more than 12 hours. Ninety-five percent reported having been undeservedly scolded or mistreated. About two in five reported having been physically abused or assaulted. Less than $30 \%$ reported getting a weekly day-off, and only $17 \%$ received festival holidays. Fortunately, almost all reported receiving annual holidays. As a gross violation of human rights, threequarters of the helping hands were reported to have been locked in from outside while their employers went out.

Most of them started working after they were 14 years or older (72.7\%), and $55.3 \%$ of respondents worked $4-7$ hours per day. The research found that $95.3 \%$ of respondents experienced rude behaviors, with $39.3 \%$ being beaten. Only $29.3 \%$ enjoyed a weekly day-off, and $17.3 \%$ enjoyed festival holidays. As a violation of the 'Domestic Worker Rights 2015', 91.3\% did not receive any signed contract before starting work (Table 2).

Our research also found that $92 \%$ of helping hands considered their work as physically challenging and $68.7 \%$ felt fatigued most of the time. Moreover, $71.3 \%$ had to work while being sick where- 


\begin{tabular}{|c|c|c|c|c|}
\hline Characteristics & Number (\%) & $\begin{array}{c}\text { Feeling safe at work } \\
\text { n (\%) }\end{array}$ & $\begin{array}{c}\text { Feeling unsafe at work } \\
\text { n (\%) }\end{array}$ & P-value \\
\hline Gender & & & & $.000^{2}$ \\
\hline Female & $276(92.0)$ & $76(27.5)$ & $200(72.5)$ & \\
\hline Male & $24(8.0)$ & 22 (91.6) & $2(8.4)$ & \\
\hline Age (Years) & & & & $.141^{1}$ \\
\hline Not known & $60(20.0)$ & $22(36.6)$ & $38(63.4)$ & \\
\hline Under 12 & $34(11.3)$ & $6(17.6)$ & $28(82.4)$ & \\
\hline 13 to 19 & $88(29.3)$ & $26(29.5)$ & $62(70.5)$ & \\
\hline $20+$ & $118(39.3)$ & $44(37.3)$ & $74(62.7)$ & \\
\hline Marital status & & & & $.000^{1}$ \\
\hline Single & $180(60.0)$ & $40(22.2)$ & $140(77.8)$ & \\
\hline Married & $54(18.0)$ & $34(62.9)$ & $20(37.1)$ & \\
\hline Divorce & $12(4.0)$ & $4(33.3)$ & $8(66.7)$ & \\
\hline Widow & $54(18.0)$ & $20(37.0)$ & $34(73.0)$ & \\
\hline Education & & & & $.000^{1}$ \\
\hline No formal schooling & $34(2.7)$ & $30(88.2)$ & $4(11.8)$ & \\
\hline Completed primary schooling & $258(86.0)$ & $64(24.8)$ & $194(75.2)$ & \\
\hline Completed high schooling & $8(11.3)$ & $4(50.0)$ & $4(50.0)$ & \\
\hline Monthly income (Taka) & & & & $.000^{1}$ \\
\hline Less than 1000 & $32(10.7)$ & $0(0.0)$ & $32(100.0)$ & \\
\hline $1000-3000$ & $76(25.3)$ & $2(2.6)$ & $74(97.4)$ & \\
\hline $3001-5000$ & $94(31.3)$ & $14(14.9)$ & $80(85.1)$ & \\
\hline More than 5000 & $98(32.7)$ & $82(83.6)$ & $16(16.4)$ & \\
\hline Total & $300(100.0)$ & $98(32.6)$ & $202(67.4)$ & \\
\hline
\end{tabular}

Table 1: Socio-demographic characteristics of the sample helping hands and their self-perceived feeling of 'safety' $(n=300)$. ${ }^{1}$ P-values from Chi-square tests; ${ }^{2}$ p-values from Fisher's exact test; BDT: Bangladeshi Taka.

\begin{tabular}{|l|c|}
\hline Characteristics & n (\%) \\
\hline Working pattern & \\
\hline Part-time & $197(65.6)$ \\
\hline Full-time & $103(34.4)$ \\
\hline Work Type & \\
\hline Domestic Worker & $295(98.33)$ \\
\hline Personal Driver & $5(1.6)$ \\
\hline Job satisfaction & \\
\hline Yes & $18(6.0)$ \\
\hline No & $290(94.0)$ \\
\hline
\end{tabular}

\begin{tabular}{|l|c|}
\hline Characteristics & n (\%) \\
\hline Salary on time & \\
\hline Yes & $98(32.7)$ \\
\hline No & $202(67.3)$ \\
\hline Starting age of working (Years) & \\
\hline Below 14 & $82(27.3)$ \\
\hline Above 14 & $218(72.7)$ \\
\hline Duration of working hour & \\
\hline $4-7$ & $166(55.3)$ \\
\hline $8-9$ & $26(8.7)$ \\
\hline
\end{tabular}




\begin{tabular}{|c|c|}
\hline Characteristics & n (\%) \\
\hline $10-11$ & $44(14.7)$ \\
\hline $12+$ & $64(21.3)$ \\
\hline \multicolumn{2}{|l|}{$\begin{array}{l}\text { Undeservedly scolded or treated } \\
\text { roughly }\end{array}$} \\
\hline Yes & $286(95.3)$ \\
\hline No & $14(4.7)$ \\
\hline \multicolumn{2}{|l|}{ Physically assaulted } \\
\hline Yes & $118(39.3)$ \\
\hline No & $182(60.7)$ \\
\hline \multicolumn{2}{|l|}{ Full day off during the week } \\
\hline Yes & $88(29.3)$ \\
\hline No & $212(70.7)$ \\
\hline \multicolumn{2}{|l|}{ Getting annual leaves } \\
\hline Yes & $282(94.0)$ \\
\hline No & $18(6.0)$ \\
\hline \multicolumn{2}{|l|}{ Getting festive holidays } \\
\hline Yes & $52(17.3)$ \\
\hline No & $248(82.7)$ \\
\hline \multicolumn{2}{|l|}{ Getting need based holidays } \\
\hline Yes & $190(63.3)$ \\
\hline No & $110(36.7)$ \\
\hline \multicolumn{2}{|l|}{$\begin{array}{l}\text { Locking of the main gate while } \\
\text { staying alone }\end{array}$} \\
\hline Yes & $222(74.0)$ \\
\hline No & $78(26.0)$ \\
\hline \multicolumn{2}{|l|}{$\begin{array}{l}\text { Written consent before starting } \\
\text { work }\end{array}$} \\
\hline Yes & $26(8.7)$ \\
\hline No & $274(91.3)$ \\
\hline
\end{tabular}

Table 2: Working situation of the sample helping hands $(n=300)$.

as, and $29.3 \%$ got treatment facilities provided by their employers while they were sick (Table 3).

Univariate and multivariate analysis of data found that being female (OR 0.016, 95\% CI 0.002-0.157), suffering from any diseases (OR 0.187, 95\% CI 0.052-0.670) and, getting salary timely (OR $0.265,95 \% 0.104-0.678$ ) were found protective factors whereas, working as a helping hand is physically hard (OR 4.595, 95\% CI 1.680-12.569), locking of the main gate while staying alone (OR $4.595,95 \%$ CI 1.680-12.569) and the number of household work

\begin{tabular}{|l|c|}
\hline Characteristics & n (\%) \\
\hline $\begin{array}{l}\text { Is working as a helping hand physically } \\
\text { hard? }\end{array}$ & \\
\hline Yes & $276(92.0)$ \\
\hline No & $24(8.0)$ \\
\hline Felt fatigued most of the time? & \\
\hline Yes & $206(68.7)$ \\
\hline No & $94(31.3)$ \\
\hline Needed to work while being sick? & \\
\hline Yes & $214(71.3)$ \\
\hline No & $86(28.7)$ \\
\hline Got treatment arranged by employers? & \\
\hline Yes & $88(29.3)$ \\
\hline No & $212(70.7)$ \\
\hline Got help while being sick? & \\
\hline Financial & $20(6.7)$ \\
\hline Leave & $218(72.7)$ \\
\hline No help & \\
\hline
\end{tabular}

Table 3: Opinion of sample helping hands-on selected health and wellbeing issues $(n=300)$.

for (OR 4.667, 95\% CI 1.567-13.900) were found as potential risk factors concerning the work safety (Table 4).

\section{Discussion}

In Bangladesh, information on the condition of the domestic helping hands (DHH) is scarce. Research focusing on their work safety is scarcer. This research tried to gather some preliminary information on the condition of a particular group of DHHs living in Dhaka city. Collecting such information is always challenging as the potential respondents are part of an invisible group of the labor force, and getting access to them is difficult if not nearly impossible. From this perspective, this is a pioneering research effort.

Our research indicated that most of the helping hands we reached out to were female, single, and completed primary education. An ILO report in 2019 also found that in Bangladesh, a majority of helping hands were female. The ILO report found most of them to be married and illiterate, who tend to differ from our research [9]. The difference is perhaps due to the fact that our research was only conducted in Dhaka city whereas the report from ILO repre- 


\begin{tabular}{|c|c|c|c|c|}
\hline \multirow[t]{2}{*}{ Variables } & \multicolumn{2}{|c|}{ Unadjusted } & \multicolumn{2}{|c|}{ Adjusted } \\
\hline & OR $(95 \% \mathrm{CI})$ & P-value & OR $(95 \% \mathrm{CI})$ & P-value \\
\hline \multicolumn{5}{|l|}{ Gender } \\
\hline Female & \multicolumn{4}{|c|}{ Reference } \\
\hline Male & $.035(.008-.150)$ & .000 & $.016(.002-.157)$ & .000 \\
\hline \multicolumn{5}{|c|}{ Working as a helping hand is physically hard } \\
\hline No & \multicolumn{4}{|c|}{ Reference } \\
\hline Yes & $7.350(2.815-19.193)$ & .000 & $8.263(1.446-47.220)$ & .018 \\
\hline \multicolumn{5}{|c|}{ Suffering from any diseases during working period } \\
\hline No & \multicolumn{4}{|c|}{ Reference } \\
\hline Yes & $4.198(2.128-8.283)$ & .000 & $.187(.052-.670)$ & .010 \\
\hline \multicolumn{5}{|c|}{ Locking of the main gate while staying alone } \\
\hline No & \multicolumn{4}{|c|}{ Reference } \\
\hline Yes & $9.102(5.080-16.309)$ & .000 & $4.595(1.680-12.569)$ & .003 \\
\hline \multicolumn{5}{|c|}{ Number of household work for } \\
\hline 1 & \multicolumn{4}{|c|}{ Reference } \\
\hline $2-3$ & $2.413(1.421-4.098)$ & .001 & $4.667(1.567-13.900)$ & .006 \\
\hline \multicolumn{5}{|c|}{ Salary on time } \\
\hline No & \multicolumn{4}{|c|}{ Reference } \\
\hline Yes & $.147(.086-.251)$ & .000 & $.265(.104-.678)$ & .006 \\
\hline
\end{tabular}

Table 4: Univariate and multivariate analysis to find out the association of independent and dependent variables.

sented the whole of Bangladesh. Our research also showed the majority of the helping hands worked 4 to 8 hours daily and almost all were undeservedly scolded or mistreated (95\%). Forty percent of the helping hands were physically abused or assaulted by their employers. Such results are close to what was reported by the International Domestic Workers Federation (IDWF), which mentioned the mean working time to be 10.73 hours and $83 \%$ and $47 \%$ were treated roughly or physically abused/assaulted, respectively.

Our research found that only one-third of the helping hands were getting treatment while being sick. Fortunately, they obtained leave without being terminated from work when sick. Getting a timely salary is very influential for an employee's motivation, and our research also found the same [16,17]. The work of domestic workers sometimes leads to different kinds of accidents, including burns. According to the World Health Organization (WHO), 80$90 \%$ of burns in Bangladesh and Ethiopia originate from household kitchens [18]. In Bangladesh, there is a common practice to lock in the helping hands [19]. Such a practice is humiliating and a gross violation of human rights which, in some cases, leads to suicide [20].

\section{Conclusion}

The study concludes that Domestic Helping Hands in Dhaka city live vulnerable lives with little safety in their working place, meager financial benefits, and lack of access to basic rights such as education, treatment, mobility, rest, and leave. The main reasons for their vulnerabilities are not limited to lack of respective authority, lack of alternative opportunities, and lack of awareness among host family members. Therefore, appropriate measures are needed to improve the work safety of helping hands such as Complaint Response Mechanism (CRM), Insurance policy, DHH association, and Legal policy.

\section{Declaration of Conflicting Interest}

The authors are declaring that there are no potential conflicts of interest with respect to this research, authorship and/or publication of this article. 


\section{Funding}

No funding.

\section{Bibliography}

1. Sourav M R I. "In Quest of a Legal Framework for Domestic Workers in Bangladesh". Journal of Malaysian and Comparative Law 41.2 (2014).

2. Islam M S and Amin M A. "Understanding domestic workers protection and welfare policy and evaluating its applications to managing human resources of informal sector in Bangladesh". Asian Economic and Social Society 6.12 (2016).

3. WIENGO. Domestic Workers 2021 [cited 20215 June]. Available from: wiego.org/informal-economy/occupationalgroups/domestic-workers.

4. International Labour Organization. Who are domestic workers ? 2021 [Available from: https://www.ilo.org/global/topics/domestic-workers/WCMS_209773/lang--en/index.htm.

5. Save the Children Sweden Denmark. Living inside room outside law (2010).

6. Amin M A. "Study: 33\% of domestic help in Dhaka are children". Dhaka Tribune (2019).

7. Islam E., et al. "Situation of Child Domestic Workers in Bangladesh". Global Journal of Management and Business Research Finance 13.7 (2013).

8. Islam M R. "National Human Rights Commission, Bangladesh". Study Report on Regulating the Unregulated Domestic Works by Children (2014).

9. Domestic Workers: Bangladesh Labour Foundation; 2020 [cited 20207 April]. Available from: http://www.blf-bd.org/ domestic-workers/.

10. International Domestic Workers Federation 2018 [Available from:https://idwfed.org/en/updates/bangladesh-cabinetclears-draft-policy-to-protect-domestic-workers-rights/domestic-workers-in-bangladesh-by-dwrn.pdf.

11. Ahmed Z. "Bangladeshi domestic workers face physical and sexual abuse in Saudi Arabia”. DW (2018).
12. Islam M. "Domestic workers rights in Bangladesh". The Daily Star (2021).

13. Ashraf A A. "Migrating out of Poverty. Public Policy Formulation: A Case Study of Domestic Workers in Bangladesh" (2019).

14. The World Bank. Poverty headcount ratio at national poverty lines (\% of population) - Bangladesh (2021).

15. Cochran W G. Sampling Techniques (3 ed.). New York: John Wiley and sons (1977).

16. A I. "Impact of Extrinsic Rewards on Employees' Performance". Journal of Global Economics 4.3 (2016).

17. Chauhan Anushree DGM and Dr. Arora Ritu Gandhi. "A review on factors influencing employee motivation". AR/ Journal of Medical and Clinical Science 4.2 (2014).

18. World Health Organization. Burns 2020 [cited 20206 April]. Available from: https://www.who.int/news-room/factsheets/detail/burns.

19. Jakir Hossain AA and Shamal Chandra Barman. "Understanding the Demand and Supply Chain of Domestic Service Work in Line with the Urban and Rural Linkages" (2015).

20. Salehin M M. Islamic NGOs in Bangladesh Development, Piety and Neoliberal governmentality: Routledge (2018).

\section{Volume 5 Issue 11 November 2021 (C) All rights are reserved by Rubaiul Murshed., et al.}

